\title{
BENTUK PERLINDUNGAN HUKUM BAGI NASABAH TERHADAP PEMBOBOLAN REKENING NASABAH OLEH PEGAWAI BANK
}

\author{
Riadhi Tedi Putra, I Nyoman Putu Budiartha, Ni Made Puspasutari Ujianti \\ Fakultas Hukum Universitas Waemadewa, Denpasar-Bali, Indonesia
}

\begin{abstract}
Abstrak
Perlindungan hukum bagi nasabah selaku konsumen di sektor perbankan menjadi sebuah hal yang urgen, mengingat telah banyak munculnya kejadian pencurian uang melalui pembobolan rekening nasabah, yang bahkan justru oleh pegawai bank sendiri. Jenis kejahatan perbankan yang diamati dalam penelitian ini adalah kejahatan perbankan yang melibatkan pegawai bank. Pemilihan jenis kejahatan yang melibatkan pegawai ini didasarkan pada kenyataan bahwa mayoritas kejahatan perbankan yang akhir-akhir ini terjadi dilakukan oleh orang yang terlibat sebagai pengelola bank, sehingga faktor penyebabnya perlu segera diketahui demi menentukan tindakan pencegahan yang tepat. Berdasarkan hal tersebut, kajian mengungkap dua isu: (1) bentuk perlindungan hukum terhadap nasabah bank terkait pencurian uang mereka melalui pembobolan rekening milik nasabah tersebut oleh pegawai bank dan (2) pertanggung jawaban bank atas pencurian uang yang dilakukan melalui pembobolan rekening nasabah oleh pegawai bank itu sendiri. Penelitian ini menggunakan metode penelitian normatif dengan pendekatan Pendekatan-statute approach, case approach, dan conceptual approach. Hasil penelitian menunjukan, perlindungan hukum terhadap nasabah bank terkait pencurian uang melalui melakukan pembobolan rekening milik nasabah oleh pegawai bank terealisasi dalam bentuk peneguran terhadap pelaku pembobolan. Pertanggung jawaban pihak bank atas pembobolan rekening nasabah oleh pegawainya, penghimpunan dan pengelolaan dana nasabah yang menjadi korban pembobolan dimaksud itu dilakukan dengan didasarkan atas prinsip kepercayaan untuk menjamin keamanan simpanan masyarakat pada bank.
\end{abstract}

Kata kunci: Nasabah; Perlindungan Hukum; Perbankan

\begin{abstract}
Legal protection for customers as consumers in the banking sector is an urgent matter, considering that there have been many incidents of theft of money through customer account hacking, even by bank employees themselves. The type of banking crime observed in this study is a banking crime involving bank employees. The choice of this type of crime is based on the fact that the majority of banking crimes that have recently occurred are committed by people involved as bank management team, so the causative factors need to be found immediately in order to determine the appropriate preventive measures. Based on this, the study uncovers two issues: (1) the form of legal protection for the bank customer regarding the theft of their money through the hacking of their account by a bank employee and (2) the bank's liability for the theft of money that is committed through hacking of the customer account by bank the employee itself. This study uses a normative research method with a statute approach, a case approach, and a conceptual approach. The results showed that legal protection for bank customer with regard to the theft of money through hacking of customer account by bank employee was realised in the form of a warning against the offender of the hacking. The liability of the bank for the hacking of the customer account by its employee is through the collection and management of customer funds who was the victim of such hacking was carried out based on the principle of trust to ensure the safety of public deposits in the bank.
\end{abstract}

Keywords: Customer; Legal Protection; Banking 


\section{PENDAHULUAN}

Bank adalah suatu badan usaha yang menghimpun dana dari masyarakat dalam bentuk simpanan dan menyalurkan kepada masyarakat dalam bentuk kredit dana atau bentuk-bentuk lainnya dalam rangka meningkatkan taraf hidup rakyat banyak. Setiap usaha bank yang dijalankan selalu menghadapi risiko. Dalam duni perbankan kecurangan merupakan penipuan yang memang disengaja dilakukan oleh sebagian seseorang atau sebagian kelompok orang sehingga menimbulkan kerugian tanpa disadari oleh pihak yang dirugikan tersebut dan memberikan keuntungan bagi pelaku kecurangan. Karena maraknya terjadi kecurangan yang disebabkan karena ketidak puasan sebagian oknum sehingga mereka mencari cara agar bagaimana caranya mendapatkan hasil yang bagus tanpa cara atau prosedur yang baik. Sehingga hal ini tidak dipungkiri menyebabkan banyaknya fraud atau kecurangan dalam bahasa perbankan, jika ini terus menerus terjadi maka terjadi pailit pada bank tersebut.

Jadi melalui dasar penjelasan tersebut, bank mempunyai fungsi sebagai sarana mobilisasi dalam melakukan berbagai kegiatan yang menyangkut perbankan. Fungsi bank ini diperlukan bagi perkembangan perekonomian suatu negara dan peningkatan standar taraf hidup masyarakat. Oleh karena fungsi bank tersebut yang sangat krusial bagi perekonomian suatu negara, maka keberadaan usaha bank harus berdasarkan prinsip kepercayaan, mengapa kepercayaan itu penting? Logika saja, dari pengertian bank saja mengartikan sebagai pihak kepercayaan untuk menyimpan uang atau transaksi perbankan lainnya. Maka untuk menjaga kepercayaan itu dibutuhkan sebuah usaha yang matang, atau bagaimana caranya agar mendapat nasabah atau menjaga nasabah lama agar tidak kehilangan kepercayaan (Djumhana, 2008).

Adanya perlindungan hukum bagi nasabah selaku konsumen di bidang perbankan menjadi urgent, mengingat adanya banyak kejadian pencurian uang dengan melakukan pembobolan rekening nasabah justru oleh pegawai bank sendiri. Jenis kejahatan perbankan yang akan diamati dalam penelitian ini adalah kejahatan perbankan yang melibatkan pegawai bank. Pemilihan jenis kejahatan yang melibatkan pegawai ini didasarkan pada kenyataan bahwa mayoritas kejahatan perbankan yang akhir-akhir ini banyak ditemukan merupakan kejahatan yang dilakukan oleh orang yang terlibat di dalam bank, sehingga perlu segera diketahui faktor penyebab dan menentukan tindakan pencegahan yang tepat.

Terkait tidanakan pembobolan bank, baik yang dilakukan oleh pegawai bank maupun oleh pihak lain telah dikaji oleh beberapa peneliti dalam satu abad terkahir, termasuk Tiffany (2012), Nugraha dkk. (2016), Utami \& Taufiq (2018), Bukit (2019). Penelitian mereka mengungkap tentang pertanggung jawaban pelaku dan pertanggung jawaban bank, dan juga perlindungan hukum bagi nasabah yang mengalami tindakan pembobolan dimaksud dan menjadi korban. Namun, penelitian yang serupa belum dilakukan di wilayah Bali. Apakah bentuk perlindungan hukum dan pertanggung jawaban pihak bank atas tindakan tersebut sama dengan ditemukan oleh peneliti sebelumnya atau tidak?

Berdasarkan posisi penelitian-penelitian sebelumnya, kajian ini menelaah tentang dua isu di wilayah pemerintah Provinsi Bali, yakni: (1) bentuk perlindungan hukum terhadap nasabah bank terkait pencurian uang dengan melakukan pembobolan rekening milik nasabah oleh pegawai bank dan pertanggung jawaban bank atas pencurian uang dengan melakukan pembobolan rekening oleh pegawai bank.

\section{METODE PENELITIAN}

Dalam melakukan penelitian ini digunakan jenis penelitian yang bersifat normatif. Penelitian Hukum Normatif merupakan penelitian yang dilakukan dengan cara mengkaji peraturan perundang-undangan yang berlaku atau diterapkan terhadap suatu permasalahan hukum tertentu. terdapat beberapa pendekatan. Dengan pendekatan tersebut, peneliti mencari berbagai informasi dari berbagai aspek mengenai isu yang sedang dikaji menemukan jawabannya yaitu perlindungan hukum bagi nasabah bank dalam hal terjadinya pencurian uang dengan melakukan pembobolan rekening nasabah oleh pegawai bank. Pendekatan-pendekatan yang digunakan di dalam penelitian hukum adalah pendekatan perundang-undangan (statute approach), pendekatan kasus (case approach), dan pendekatan konseptual (conceptual approach).

Sumber bahan hukum dalam penelitian ini terdiri dari bahan hukum primer dan bahan hukum sekunder. Bahan hukum primer adalah bahan hukum yang mempunyai kekuatan mengikat umum yang diperoleh dari peraturan perundang-undangan. Bahan hukum sekunder adalah bahan hukum 
yang bersumber dari studi kepustakaan seperti buku, bahan hukum yang dikumpulkan dari internet yang memiliki buhungan dengan objek penelitian ini. Pengumpulan bahan-bahan hukum primer dan sekunder dilakukan dengan cara pencatatan dan dokumentasi tentang permasalahan yang diteliti. Adapun teknik pengolahan dan analisa hukum di dalam penulisan ini yakni dilakukan secara deskriptif dan menyesuaikan dengan argumentasi hukum. Selanjutnya bahan hukum tersebut diuraikan secara deskriptif guna memperoleh gambaran yang dapat dipahami secara jelas dan terarah untuk menjawab permasalahan. Selanjutnya data dievaluasi serta dihubungkan dengan permasalahan yang ada sehingga dapat ditarik suatu kesimpulan.

\section{HASIL DAN PEMBAHASAN Bentuk Perlindungan Hukum bagi Nasabah dari Pembobolan (Pencurian) Rekening Nasabah oleh Pegawai Bank}

Perlindungan hukum memang merupakan sesuatu yang harus ada di dalam negara hukum, karena perlindungan hukum itu merupakan tindakan untuk melindungi keresahan dari yang merasa terugikan maupun dirugikan, dengan adanya perlindungan hukum ini sebenarnya merupakan memberikan rasa nyaman dan aman. Seperti yang diketahui semua orang bank mempunyai peran penting dalam dunia perbankan, dan juga dibutuhkan juga perlindungan hukum bagi nasabah andai kata terjadi suatu hal yang merugikan nasabah, jadi nasabah bisa menggunakan perlindungan tersebut untuk menuntut ganti rugi atau sejenisnya (Sembiring, 2006). Wujud perlindungan itu dasarnya merupakan cara untuk mendapatkan perlindungan atau terlindungi, perlunya melalui tahap konseptual ini yang perihal untuk menyelaraskan antar hubungan kaedah-kaedah dalam perlindungan hukum di dunia perbankan (Soekanto, 1984).

Upaya perlindungan konsumen dalam sejarahnya mencakup dua macam adagium, yaitu caveat emptor (waspadalah konsumen) yang kemudian berkembang menjadi caveat venditor (waspadalah pelaku usaha). Perkembangan kedua caveat itu erat kaitannya dengan perkembangan paham dan periode tertentu. Ceveat emptor tidak terlepas paham liberalisme dengan prinsip kebebasan berkontrak. Titik kulminasi dicapai dalam Revolusi Perancis dan Revolusi Industri. Revolusi Perancis membebaskan manusia dari belenggu perhimpunan-perhimpunan ahli-ahli pertungan atau serikat pekerja ("gilden").Pada masa ini paham liberalisme sangat menguasai sistem perdagangan dengan pasar bebas, dimana "sejalan dengan kebebasan yang sama dan kesamaan kesempatan yang fair" (Rawls, 1999). Memberikan kesempatan bagi semua orang dengan peluang yang sama dimana terdapat kesetaraan dalam kemampuan dan posisi tawar di antara mereka. Kesetaraan yang diberikan kepada setiap orang sesuai dengan prinsip keadilan pada masa tersebut, yaitu keadilan komutatif. Kedudukan pihak nasabah sebagai konsumen dan pihak bank sebagai pelaku usaha menjadikan bank harus bertanggung jawab terhadap kerugian yang dialami nasabahnya. Agar kasus-kasus yang demikian tidak terulang atau dapat diminimalisir, maka sudah seharusnya bank menjalankan kegiatan usahanya denga prinsip kehati-hatian dan meningkatkan pengawasan internalnya (Sulistyandari, 2011).

Oleh sebab itu, makanya hubungan antar nasabah dan bank memang harus seperti ikatan keluarga dan harus memberikan kepercayaan penuh kepada nasabah, karena nasabah itu merupakan seorang yang mampu menmerikan kesejahteraan dalam bank itu sendiri, semakin banyak nasabah itu juga mempengaruhi nama bank tersebut, dan jika pemasaran bank itu pintar dan mempunyai logika stategis, maka tidak dipungkiri lagi banyak nasabah yang tertarik, dibarengi dengan sebuah kegiatan semacam pemberian hadiah demi kepuasan nasabah itu sendiri, dan kemauan masyarakat untuk menyimpan uangnya di bank.

\section{Bagaimanakah Tanggung Jawab Bank terhadap Pencurian Uang dengan Melakukan Pembobolan Rekening oleh Pegawai Bank}

Bank merupakan hal yang sangat penting dalam kebutuhan masyarakat zaman sekarang, bank ini mempunyai peran yang cukup penting, karena lembaga perbankan khususnya bank umum, merupakan inti sari dari system keuangan setiap Negara. Begitu banyaknya istilah dalam dunia perbankan membuat kita sangat dalam tanda kutip bingung dengan istilah- istilah tersebut salah satunya nasabah, nasabah ya dalam arti umumnya adalah seseorang yang menyimpan uang atau dananya di bank yang dipercayainya, oleh sebab itu ada 2 (dua) jenis nasabah yang kita kenal saat ini, yaitu nasabah debitur dan nasabah penyimpan. Dari nama saja sudah tahu pengertiannya, nasabah debitur merupakan 
nasabah yang di berikan fasilitas kredit dengan perjanjian yang sudah disepakati oleh bank, sedangkan nasabah penyimpan merupakan orang yang merasa aman dan nyaman untuk menyimpan uangnya di bank sebagai bentuk bukti kepercayaan dengan bank bersangkutan. Masyarakat yang melakukan transaksi langsung di bank tanpa memiliki simpanan atau juga bisa dikategorikan sebagai nasabah. Dalam suatu kasus yang sering menjadi rujukan, yaitu kasus United Dominations Trust Ltd. V. Kirkwood, Lord Denning menyebutkan peran seroang banker adalah sebagai berikut: Menyiapkan yang namanya safe custody melalui dana-dana pihak ketiga; Menyipakan hitungan rekening bagi nasabah yang menjadi kepercayaan; Biasanya sebagai agen untuk melakukan penarikan; Melunasi dana yang di tarik tunai oleh nasabah (Djumhana, 1993).

Dampak selanjutnya dari keadaan tersebut akan dapat mengancam perekonomian dan system perbankan nasional. Kepercayaan masyarakat akan goyah, rush akan terjadi dan multiplier efeknya akan dapat menular ke industri bank yang lain, bahkan pada system perekonomian Negara. Dengan demikian, tujuan utama bank bekerja dengan menggunakan prinsip rahasia bank adalah agar nasabah memperoleh tingkat perlindungan dan penjaminan hukum yang memadai atas kepercayaan nasabah yang diberikan kepada bank untuk mengelola dana yang disimpannya tersebut. Nasabah akan merasakan memperoleh jaminan perlindungan hukum bahwa dana yang dipercayakan kepada bank tersebut tidak akan disalahgunakan untuk hal-hal yang sangat mengganggu privasi dari si nasabah, antara lain dalam hal kerahasiaan nasabah dan simpananya.

Dalam era globalisasi saat ini dengan kemajuan teknologi sangat pesat ini, bisa dibilang ada enaknya ada juga tidak mengenakan, disatu sisi pasti kita butuh atau di untungkan dengan teknologi agar lebih cepat dan efisien, namun sisi gelapnya dibalik semua itu pasti ada sisi buruknya, contoh beberapa modus penipuan dalam perbankan melalui situs komersial di internet. Dimana nomer rekening nasabah tersebut akan dilihat oleh tersangka di situs situs non secure atau jaringan internet yang berbahaya. Disitulah bisa saja nomer rekening kita sudah di ketahui dan dipergunakan atau dibobol oleh pelaku tersebut. Nomor rekening tersebut digunakan untuk membeli barang yang akan dijual melalui situs tadi. Sebelum menggunakan nomor rekening tersebut tersangka terlebih dahulu melihat kemampuan keuangan pemilik rekening, dan setelah mendapat kepastian finansialnya, tersangka segera memesan barang-barang tertentu dengan menggunakan nomor rekening milik orang lain tersebut.

Dengan adanya kejadian tersebut pihak bank akhirnya mencari solusi dimana bank membuat proteksi dengan memberikan kode rahasia misalnya dengan sandi $\mathrm{x}$ dan $\mathrm{xx}$. Atau dengan mengganti rekening nasabah dengan bank card yaitu berupa kartu berbahan plastik yang diberikan oleh pihak bank kemudian kartu tersebut diberikan semacam urgent code yang bersifat sementara di keadaan darudat dan kemudian bisa dipergunakan di supermarket atau swalayan untuk membantu di situasi darurat seperti itu. Disamping solusi yang diambil oleh bank dalam upaya mengantisipasi kejahatan pencurian uang dengan melakukan pembobolan rekening nasabah tersebut, hak pemerintah hendaknya menciptakan, memelihara dan mempertahankan kedamaian perlu mempertimbangkan dalam penegakan hukum merupakan faktor yang memang dibutuhkan dalam berbagai badan usaha di Indonesia, karena apapun jenis badan usahanya harus berbadan hukum di Indonesia, karena sudah di atur dalam perundang-undangan di Indonesia, faktor hukum ini butuh juga dari faktor masyarakat yang diperlukan sebuah displin hukum agar membuat negara lebih maju, setelah itu apabila bank melakukan yang melanggar hukum bank harus ditindak juga agar tidak sewenang-wenang dalam menjalankan badan di Indonesia.

Jadi, yang boleh diinformasikan hanyalah keterangan mengenai simpanannya. Jika ketentuan Pasal 42 ini dikaitkan dengan ketentuan Pasal 40, terlihat dapat menjadi kontradiksi karena Pasal 40 menentukan bahwa yang wajib dirahasikan adalah nasabah dan simpanannya. Mengapa dibedakan antara nasabah (subjek) dan simpananya (objek)? Pasal 42 mengatur yang boleh diinformasikan adalah objeknya. Persoalannya, mungkinkah menginformasikan simpanan (objek) itu tanpa implisit termasuk menginformasikan keterangan tentang diri nasabah (subjek). Tidak tertutup kemungkinan pertanyaan-pertanyaan diatas menjadi masalah di dalam praktik. Oleh sebab itu, hakim harus sangat bijak dan hati-hati dengan menggunakan pendekatan keadilan dan kemanfaatan dan tidak harus selalu mengedepankan tungku kepastian hukum dengan menggunakan pendekatan normatif semata. 


\section{SIMPULAN DAN SARAN}

\section{Simpulan}

Berdasarkan uraian yang diuraikan di atas simpulan penelitian ini ialah sebagai berikut:

1. Bentuk perlindungan hukum terhadap nasabah bank terkait pencurian uang dengan melakukan pembobolan rekening nasabah milik nasabah oleh pegawai bank yaitu bank bersikap tegas kepada pegaiwanya, apabila tindakan melalui surat peringatan tidak juga bisa untuk membuat pegawai itu tekun maka tindakan pemecatan wajib dilakukan, itu agar membuat citra bank itu sendiri agar lebih baik lagi, apabila nama citra suatu bank itu baik maka para nasabah akan mempercayai bank tersebut untuk melakukan kegiatan yang berhubungan dengan kegiatan perbankan, oleh sebab itu hubungan antar nasabah dan bank memang harus seperti ikatan keluarga dan harus memberikan kepercayaan penuh kepada nasabah, karena nasabah itu merupakan seorang yang mampu memberikan kesejahteraan dalam bank itu sendiri, semakin banyak nasabah itu juga mempengaruhi nama bank tersebut, dan jika pemasaran bank itu pintar dan mempunyai logika stategis.

2. Tanggung jawab bank terhadap pencurian uang dengan melakukan pembobolan rekening nasabah oleh pegawai bank telah di atur dalam Pasal 37 B UUP bahwa setiap bank wajib menjamin dana masyarakat yang disimpan pada bank yang bersangkutan terjamin dengan aman. Dengan hal tersebut bank sebagai pihak yang dipercaya sebagai tempat menyimpan uang agar memperketat apabila merekrut seorang pegawai hendaknya sesuai dengan protokoler dalam perbankan.

\section{Saran}

Bertitik tolak dari kesimpulan yang telah dikemukakan diatas dapat disarankan hal sebagai berikut:

1. Kepada pihak bank disarankan hendaknya dalam merekrutmen pegawai harus diperketat lagi karena bank merupakan sebuah bisnis kepercayaan dalam hal perbankan.

2. Kepada masyarakat, hendaknya hati-hati dalam penyimpanan dan atau meminjam uang kepada bank, karena masih banyak bank yang tidak melaksanakan prinsip kehati-hatian dan kepercayaan, dan melakukan pengcekan secara berkala dana simpanannya sehingga apabila terjadi hal yang tidak diinginkan bisa diketahui sedini mungkin.

\section{DAFTAR PUSTAKA}

Bukit, A. N. (2019). Pertanggungjawaban Bank terhadap Hak Nasabah yang Dirugikan dalam Pembobolan Rekening Nasabah (Studi di PT. Bank Rakyat Indonesia Tbk, Kantor Cabang Medan Gatot Subroto). Jurnal Ius Constituendum, 4(2), 181-194.

Djumhana, M. (1993). Hukum Perbankan di Indonesia. Citra Aditya Bakti.

Djumhana, M. (2008). Asas-asas Hukum Perbankan Indonesia. Citra Aditya Bakti.

Nugraha, F. S., Budiharto, \& Njatrijani, R. (2016). Perlindungan Hukum terhadap Nasabah Bank dalam Pembobolan Internet Banking melalui Metode Malware. Diponegoro Law Journal, 5(3), $1-13$.

Rawls, J. (1999). A Theory of Justice (Edisi Revi). Harvard University Press.

Sembiring, S. (2006). Hukum Perusahaan dalam Peraturan Perundang-Undangan. Nuansa Aulia.

Soekanto, S. (1984). Pengantar Penelitian Hukum. Universitas Indonesia Press.

Sulistyandari. (2011). Aspek Hukum Pembobolan Uang Nasabah Bank (Bagian I). Media Online Gagasan Hukum.

Tiffany, M. (2012). Perlindungan Hukum terhadap Nasabah atas Tindakan / Perilaku Fraud yang Dilakukan oleh Pegawai Bank. Syiar Hukum: Jurnal Ilmu Hukum, 14(1), 244-264.

Utami, I. T., \& Taufiq, M. (2018). Analisis Yuridis Kasus Pembobolan Rekening pada Bank Mandiri. Jurnal Living Law, 10(1), 58-77.

Kitab Undang-Undang Hukum Perdata (KUH Perdata.) Undang-Undang Nomor 10 Tahun 1998 tentang Perbankan

Undang-Undang Republik Indonesia Nomor 8 Tahun 1999 tentang Perlindungan Konsumen. 